\title{
UJI AKTIVITAS LARVASIDA NYAMUK Aedes aegypti DARI BEBERAPA EKSTRAK ASCIDIAN
}

(Test of Larvae Aedes aegypti Activity to Some Ascidian Extracts)

\author{
M. Subhan Moerid', R.E.P. Mangindaan ${ }^{2}$, F. Losung ${ }^{2}$ \\ ${ }^{1}$ Mahasiswa Program Studi IImu Kelautan, Fakultas Perikanan dan Ilmu Kelautan, \\ Universitas Sam Ratulangi, Manado. \\ ${ }^{2}$ Staf Pengajar Program Studi IImu Kelautan, Fakultas Perikanan dan IImu Kelautan, \\ Universitas Sam Ratulangi, Manado.
}

\begin{abstract}
Dengue Hemorrhagic Fever (DHF) is a disease caused by virus through Aedes aegypti mosquitoes as the vector. The disease is spreading across the world and endanger and threaten human life. Measures in controlling the vector using the common larvaside rábateò are in adequate and less affective. The objectives of the research is to find out larvaside extracted from three kinds of ascidian. The each ascidians (Polycarpa aurata, Didemnum molle and Rophalaea crassa) were extracted with ethanol, and the crude extracts were subjected to larvasidal test by dissolving in water containing the larvae. The remarkable extract activity was partition in ethyl acetate, hexane and buthanol. The results show that extract of Polycarpa aurata has the highest activity. The activity of fractions show that ethyl acetate at $100 \mathrm{ppm}$ reveals the highest mortality of larvae $100 \%$ in 8 hours, followed by hexane fraction (12 hours) then buthanol fraction (18 hours). All the fractions (Ethyl acetate, Hexane and Buthanol) could totality kill the larvae within 24 hours which is comparable to the abate.
\end{abstract}

\begin{abstract}
Keywords : Aedes aegypti, Ascidian, Polycarpa auarata, Larvasidal.
Dengue Hemorrhagic Fever (DHF) merupakan sebuah penyakit yang disebabkan oleh virus lewat perantara nyamuk Aedes aegypti. Penyakit ini menyebar di seluruh dunia dan membahayakan serta mengancam hidup manusia. Upaya-upaya pengendalian vektor menggunakan rábateòyang umum digunakan masih kurang efektif dan kurang memadai. Tujuan dari penelitian ini adalah untuk mengetahui ekstrak larvasida dari tiga jenis ascidian. Masing-masing ascidian (Polycarpa aurata, Didemnum molle and Rophalaea crassa) di ekstrak dengan ethanol, kemudian ekstrak kasar tersebut dilakukan pengujian larvasida dengan melarutkannya ke dalam air yang mengandung larva. Hasil ekstrak yang terbaik dipisahkan dengan etil asetat, heksan and butanol. Hasil penelitian memperlihatkan bahwa Polycarpa aurata mempunyai aktivitas tertinggi. Aktivitas menunjukkan bahwa fraksi etil asetat pada konsentrasi $100 \mathrm{ppm}$ mengakibatkan kematian tertinggi 100\% dari larva yang diuji dalam jangka waktu 8 jam, diikuti oleh fraksi heksan (12 jam) dan fraksi butanol (18 jam). Semua fraksi (Etil asetat, Heksan dan Butanol) dapat membunuh keseluruhan larva dalam waktu 24 jam menyamai abate.
\end{abstract}

Kata Kunci : Aedes aegypti, Ascidian, Polycarpa aurata, Larvasida.

\section{PENDAHULUAN}

Dewasa ini berbagai penyakit tropis ditularkan oleh nyamuk. Penyakit malaria misalnya ditularkan oleh nyamuk Anopeles dan demam berdarah ditularkan oleh nyamuk Aedes aegypti. Penyakit-penyakit ini menyebar di lebih 100 negara dan setengah dari populasi dunia terancam olehnya (Manuel, 1992).
Pencarian metode-metode baru untuk membasmi sumber penularan penyakit demam berdarah sangat penting dan mendesak. Menurut data dari $\mathrm{WHO}$, penyakit ini telah menulari 200 juta orang dan membunuh 1 juta orang tiap tahun di seluruh dunia. Metode yang dikembangkan oleh WHO untuk memerangi penyakit demam berdarah adalah sama seperti metode 
yang digunakan untuk memerangi penyakit malaria yaitu dengan membasmi sumber penularannya yaitu larva nyamuk (Manuel, 1992). Penelitian senyawa aktif bahan alam yang dapat digunakan sebagai agen larvasida belum banyak dilakukan.

Pattiwael (2004) melaporkan bahwa biota laut sponge Placospongia melobesiodes memiliki aktivitas larvasida yang baik. Wibowo $d k k$, (1997) melaporkan adanya aktivitas larvasida dari rimpang temu lawak. Mangindaan (2011) juga melaporkan adanya aktivitas larvasida dari ekstrak teripang getah. Berdasarkan hal-hal tersebut maka penelitian ini diharapkan bermanfaat untuk memperoleh senyawa larvasida dan alur pemurniannya dari ekstrak ascidian.

$$
\text { Menurut Sudarmo (1989), }
$$

larvasida merupakan golongan dari pestisida yang dapat membunuh serangga belum dewasa atau sebagai pembunuh larva. Lanasida berasal dari bahasa Yunani yang terdiri dari 2 suku kata, yaitu ñaròberarti serangga belum dewasa dan îsidaò berarti pembunuh. Jadi larvasida dapat diartikan sebagai pembunuh serangga yang belum dewasa atau pembunuh ulat (larva).

Pemberantasan nyamuk menggunakan larvasida merupakan metode terbaik untuk mencegah penyebaran nyamuk. Parameter aktivitas larvasida suatu senyawa kimia dilihat dari kematian larva. Senyawa bersifat larvasida terhadap larva nyamuk $A$. aegypti germacron dan turanodienon telah berhasil diisolasi dari rimpang temu lawak (Wibowo $d k k, 1997)$. Senyawa bersifat larvasida juga bisa digunakan sebagai sediaan insektisida untuk membasmi serangga yang belum dewasa dan serangga dewasa.

\section{METODE PENELITIAN}

Sampel ascidian yang diambil di perairan Malalayang Manado diekstraksi menggunakan metode yang biasa digunakan di Laboratorium Kimia Bahan
Hayati Laut. Tiga jenis sampel ascidian dengan berat basah sebanyak 600gr (Polycarpa aurata), 500gr (didemnum molle), 500gr (Rophalaea crassa) diblender lalu direndam dalam $1000 \mathrm{ml}$ etanol selama 24 jam. Selanjutnya sampel disaring dengan menggunakan kertas saring Whattman. Hasil saringan diuapkan dalam vaccum rotary evaporator pada suhu 40:\& C sampai etanol menguap. Ekstrak etanolik yang diperoleh dikeringkan dan ditimbang.

Ekstrak etanolik ditambahkan etil asetat (1:3) dan dipisahkan dalam corong pemisah. Selanjutnya fraksi etil asetat yang diperoleh diuapkan dalam vaccum rotary evaporator pada suhu 40\& C hingga kering dan selanjutnya ditimbang. Fraksi etil asetat dilarutkan kembali dalam aquades dengan menggunakan metanol dan ditambahkan heksan (1:3) dimasukkan ke dalam corong pemisah. Fraksi heksan yang diperoleh kemudian dikeringkan dan ditimbang. Fraksi airmetanol ditambahi butanol (1:3) sehingga diperoleh fraksi air-metanol dan fraksi butanol. Fraksi butanol diuapkan lalu ditimbang. Setiap fraksi (etil asetat, heksan, dan butanol) diuji aktivitas larvasidanya.

\section{Pengujian Aktifitas Larvasida}

Pengujian larvasida menggunakan metode Atta $d k k$, (2001) terhadap larva nyamuk $A$. aegypti. Sebanyak 10 ekor larva nyamuk $A$. aegypti instar III dipindahkan dari wadah penampung ke dalam gelas piala yang berisi ekstrak (sesuai konsentrasi), abate dan kontrol.. Aktivitas larvasida yang diamati selama 24 jam. Perhitungan waktu dimulai setelah pemasukkan larva ke dalam gelas piala.

Pengamatan alur hidup yaitu larva uji diberikan ekstrak mampu bertahan hidup pada jangka waktu tertentu namun tidak dapat mencapai tahap selanjutnya. Efek kematian dimaksud yaitu larva uji mengalami mortalitas akibat adanya aktivitas ekstrak larvasida yang diberikan. 
Data yang diperoleh diolah dengan menggunakan Probit Analysis.

\section{HASIL DAN PEMBAHASAN}

Dari masing ï masing berat basah sampel ascidian yang diperoleh antara lain (Polycarpa aurata) $600 \mathrm{~g}$, (Didemnum molle) 500 g, (Rophalaea crassa) $500 \mathrm{~g}$, serta berat ekstrak etanolik dan fraksi ï fraksi yang dipartisi dapat dilihat pada tabel berikut :

Tabel 1. Berat masing ï masing fraksi ascidian.

\begin{tabular}{|c|c|}
\hline Fraksi & Berat (g) \\
\hline Ekstrak etanolik (PA) & $47.00(7.8 \%)$ \\
Etil Asetat & 0.0977 \\
Heksan & 0.0327 \\
Butanol & 0.3662 \\
\hline Ekstrak etanolik (DM) & $39.07(7.8 \%)$ \\
Etil Asetat & Tidak \\
Heksan & Di \\
Butanol & Partisi \\
\hline Ekstrak etanolik (RC) & $29.00(5.6 \%)$ \\
Etil Asetat & Tidak \\
Heksan & Di \\
Butanol & Partisi \\
\hline
\end{tabular}

Dari tabel di atas dapat dilihat bahwa fraksi yang dipartisi yaitu etil asetat, heksan dan butanol hanya dilakukan pada sampel ascidian Polycarpa aurata, dikarenakan Polycarpa aurata memiliki aktivitas tertinggi dibandingkan Didemnum molle dan Rophalaea crassa pada pengujian ekstrak etanolik.

Pengujian ekstrak etanolik Polycarpa aurata pada konsentrasi 10, 100 dan 1000 ppm dapat dilihat pada Gambar 1. Pada gambar ini nampak bahwa respons mortalitas abate masingmasing konsentrasi mencapai 100\% pada jam ke 4, 6 dan 12. Pada ekstrak etanolik untuk konsentrasi 1000 ppm mencapai $100 \%$ pada jam ke 8 , sedangkan konsentrasi 100 ppm mencapai $53,3 \%$ pada jam ke 24 dan konsentrasi 10 ppm mencapai 16,6\% pada jam ke 24.



Gambar 1. Persentasi Mortalitas Larva Uji A. aegypti Terhadap Ekstrak Etanolik (Polycarpa aurata) Selama Pengamatan (Jam).

Hasil ini mengindikasikan bahwa pada konsentrasi 1000 ppm ekstrak sudah mampu memberi efek mortalitas yang baik meski masih dalam fraksi ekstrak kasar.

Untuk konsentrasi 1000 ppm pada ekstrak etanolik Didemnum molle mencapai $100 \%$ pada jam ke 20, sedangkan pada konsentrasi 100 dan 10 ppm hanya mencapai $40 \%$ dan 16.6 $\%$. Pada konsentrasi abate 10, 100 dan 1000 ppm sama dengan data sebelumnya. Persentase mortalitas dapat dilihat pada Gambar 2.

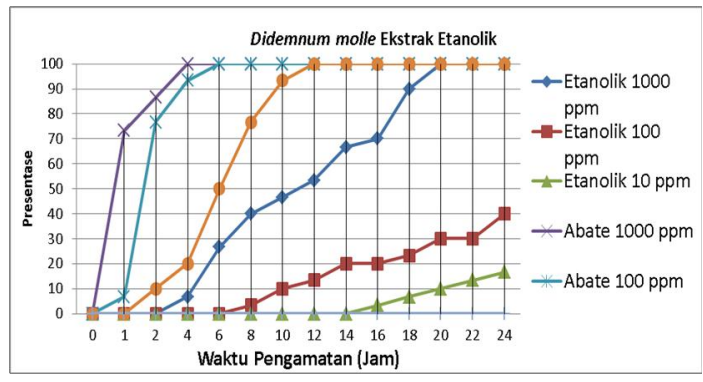

Gambar 2. Persentasi Mortalitas Larva Uji $A$. aegypti Terhadap Ekstrak Etanolik (Didemnum molle) Selama Pengamatan (Jam).

Pengujian ekstrak etanolik Rophalaea crassa pada konsentrasi 10 , 
100 dan 1000 ppm dapat dilihat pada Gambar 3. Pada gambar ini nampak bahwa respons mortalitas ekstrak etanolik sangat tidak berarti walaupun sampai pada konsentrasi 1000 ppm hanya mencapai $13,3 \%$ juga pada 100 ppm mencapai $3,3 \%$ dan pada 10 ppm tidak menunjukan respons mortalitas.

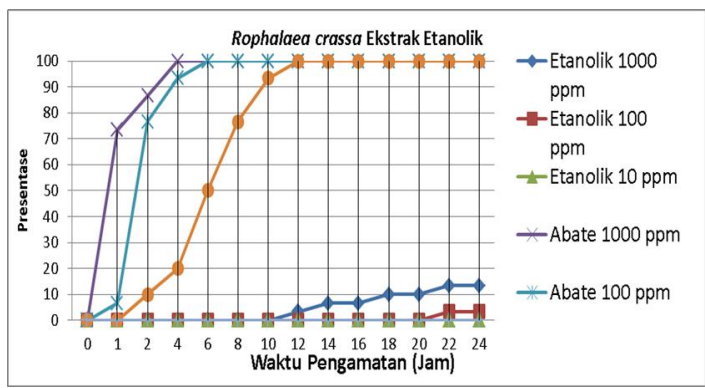

Gambar 3. Persentasi Mortalitas Larva Uji A. aegypti Terhadap Ekstrak Etanolik (Rophalaea crassa) Selama Pengamatan (Jam)

\section{Aktivitas Larvasida Fraksi Larut Etil Asetat, Heksan dan Butanol.}

Hasil perlakuan dari tiga fraksi, ascidian Polycarpa aurata dengan konsentrasi $10 \mathrm{ppm}$ dapat dilihat pada Gambar 4. Gambar ini menunjukkan bahwa respons mortalitas abate mencapai $100 \%$ pada jam ke 12 ,

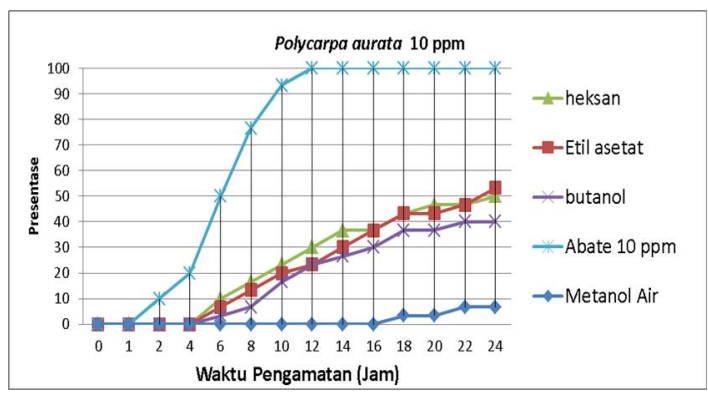

Gambar 4. Persentasi Mortalitas Larva Uji $A$. aegypti Fraksi Larut Etil Asetat, Heksan dan Butanol Pada Konsentrasi 10 ppm Selama Pengamatan (Jam). sedangkan untuk fraksi etil asetat mencapai 53,3\%, heksan $50 \%$ dan butanol 40\%. Dari data tersebut diperlihatkan bahwa konsentrasi 10 ppm belum mempunyai aktivitas yang baik, yang hanya mencapai 40 sampai $50 \%$ pada jangka waktu 24 jam pengamatan. Hasil pengamatan yang dilakukan pada konsentrasi 100 ppm pada Gambar 5, menunjukkan abate sebagai kontrol positif respons mortalitas mencapai $100 \%$ pada jam ke 5. Pada fraksi etil asetat menunjukkan mortalitas 100\% pada jam ke 8. Ini menunjukkan respons yang meningkat hingga mencapai $70 \%$ dibandingkan konsentrasi 10 ppm. Pada fraksi heksan menunjukkan respons mortalitas larva uji pada jam ke 12 mencapai $100 \%$. Sedangkan pada fraksi butanol mencapai mortalitas pada jam ke 18 mencapai $100 \%$.

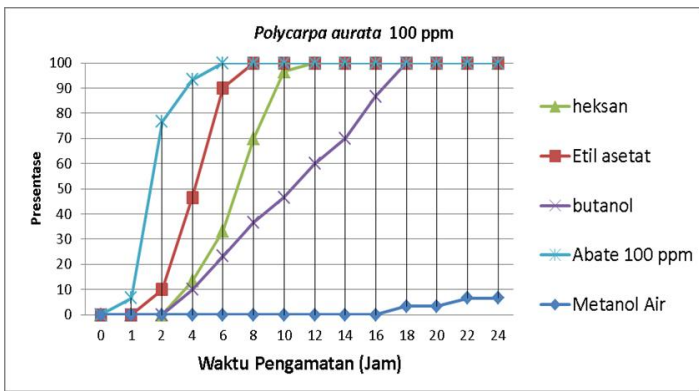

Gambar 5 .Persentasi Mortalitas Larva Uji A. aegypti Fraksi Larut Etil Asetat, Heksan dan Butanol Pada Konsentrasi 100 ppm Selama Pengamatan (Jam).

Pada Gambar 6, nampak bahwa respons mortalitas abate mencapai $100 \%$ pada jam ke 4 pada konsentrasi 1000 ppm, sama dengan fraksi etil asetat yang juga mencapai $100 \%$ pada jam ke 4. Pada fraksi heksan diperlihatkan bahwa mortalitas yang terjadi pada jam ke 8 mencapai 100\%. Efek mortalitas juga diperlihatkan oleh fraksi butanol pada jam ke 10 mencapai $100 \%$. 


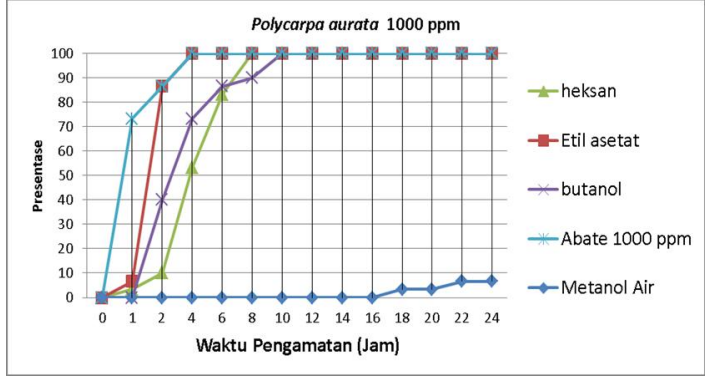

Gambar 6. Persentasi Mortalitas Larva Uji $A$. aegypti Fraksi Larut Etil Asetat, Heksan dan Butanol Pada Konsentrasi 1000 ppm Selama Pengamatan (Jam).

Pada konsentrasi 100 dan 1000 ppm fraksi larut etil asetat, heksan dan butanol sudah bisa memperlihatkan aktivitas larvasida walaupun masih terdapat perbedaan jangka waktu. Dari data yang diperoleh fraksi etil asetat dan heksan bersifat racun kontak. Djojosumarto, (2000) mengatakan bahwa racun kontak dapat membunuh karena ada kontak pada bagian luar dari salah satu anggota badan ataupun seluruh tubuh. Hal inilah yang menyebabkan respons mortalitas larva uji cenderung lebih cepat untuk memperoleh hasil maksimal.

Data pengamatan fraksi butanol dapat menggambarkan karakter senyawa aktif larvasida yang terkandung di dalamnya bersifat racun perut karena dapat dilihat perbedaan jangka waktu masing-masing fraksi pada tiap-tiap konsentrasi dimana fraksi butanol membutuhkan waktu yang panjang untuk memperoleh respons mortalitas dibandingkan fraksi etil asetat dan heksan. Racun perut merupakan racun yang merusak bagian tubuh serangga setelah masuk lewat mulut dan saluran pencernaan sehingga menghancurkan sistem pencernaan. Hal ini diketahui lewat penelitian, dimana selama pengujian aktivitas larva tidak diberikan makanan, sehingga bahan organik dari ekstrak ascidian terpaksa menjadi makanan untuk larva instar 3 yang aktif makan. Hal ini diperkuat oleh pernyataan Rozendaal (1997) bahwa sebagian besar larvasida bekerja sebagai racun perut.

\section{KESIMPULAN}

Dari pengujian 3 jenis sampel ascidian, terdapat 1 jenis yang mempunyai aktivitas tertinggi pada pengujian ekstrak etanolik yaitu Polycarpa aurata. Semua fraksi (etil asetat, heksan dan butanol) dapat membunuh keseluruhan larva dalam waktu 24 jam. Komponen aktif yang terkandung banyak terdapat pada fraksi larut etil asetat.

\section{DAFTAR PUSTAKA}

Atta, R.U., M.I. Chundary. dan W.J. Thomson. 2001. Bioassay Techniques for Drug Development. Harvard Academic Publisher. Singapore. $123 \mathrm{Hal}$.

Djojosumarto P. 2000. Teknik Aplikasi Pestisida Pertanian. Penerbit Kanisius. Yokyakarta. $211 \mathrm{Hal}$.

Mangindaan, 2011. Uji Aktivitas Larvasida Nyamuk Aedes aegypti. Laporan Hasil Penelitian Iptek dan Seni.FPIK. UNSRAT. 26 Hal.

Manuel, F. B. and Douglas, K. A., 1992, Human Medicinal Agent From Plant, American Chemical Society, Washington.D.C.

Pattiwael,M.R., 2004. Uji Aktivitas Larvasida dari Sponge Terhadap Larva Nyamuk Aedes aegypti. Skripsi. Fak. Perikanan dan IImu Kelautan. Unsrat. 56 Hal.

Rozendaal, J.A. 1997. Vektor Control Methods for Use by Individuals and Communities. Word Health Organizations. Geneva. 412 hal. 
Sudarmo, S., 1989. Pestisida Tanaman. Edisi kedua. Penerbit Kanisius Yogyakarta. 124 halaman.

Wibowo, A. E., W. Sumaryono, Milnaldi. 1997. Uji Aktivitas Larvasida dan Identifikasi Senyawa Ekstrak Rimpang Temu Lawak Terhadap Larva Nyamuk Aedes aegypti. Prosiding Seminar Nasional Hasil Dalam Bidang Farmasi. Halaman 641-650. 